\title{
First-year university students' academic success: the importance of academic adjustment
}

\author{
Els C. M. van Rooij ${ }^{1}$ • Ellen P. W. A. Jansen ${ }^{1}$ • \\ Wim J. C. M. van de Grift ${ }^{1}$
}

Received: 15 February 2017 /Revised: 4 July 2017 / Accepted: 4 August 2017 /

Published online: 4 November 2017

(C) The Author(s) 2017. This article is an open access publication

\begin{abstract}
Considering the pivotal role of academic adjustment for student success, it is important to gain insight into how several motivational and behavioural factors affect academic adjustment and the extent to which academic adjustment influences student success. This empirical study investigated how intrinsic motivation, academic self-efficacy, selfregulated study behaviour and satisfaction with the chosen degree programme influenced academic adjustment in university and how these variables and adjustment affected three important indicators of student success: grade point average (GPA), attained number of credits (ECTS) and intention to persist. The sample consisted of 243 first-year university students in the Netherlands. Structural equation modelling showed that academic adjustment was influenced by intrinsic motivation, self-regulated study behaviour and degree programme satisfaction, which together explained $72 \%$ of the variance in adjustment. Motivational and behavioural variables did not influence GPA and credits directly but through academic adjustment. Furthermore, only satisfaction with the degree programme predicted intention to persist. These results point to the importance of academic adjustment in predicting university GPA and credits and the pivotal role of satisfaction with the degree programme in predicting intention to persist. Universities could integrate the development of self-regulated study skills - the biggest contributor to academic adjustment - in the first-year programme. Moreover, looking at the importance of students' satisfaction with the programme, communication and collaboration between secondary schools and universities should be enhanced in order to
\end{abstract}

Els C. M. van Rooij

e.c.m.van.rooij@rug.nl

Ellen P. W. A. Jansen

e.p.w.a.jansen@rug.nl

Wim J. C. M. van de Grift

w.j.c.m.van.de.grift@ rug.nl

1 Department of Teacher Education, University of Groningen, Grote Kruisstraat 2/1, 9712

TS Groningen, The Netherlands 
help students to choose a university degree programme that matches their abilities, interests and values.

Keywords Academic adjustment - Achievement · Persistence - Motivation - Self-regulation · Degree programme satisfaction

\section{Introduction}

Drop-out rates in the first year of university are high worldwide. In the Netherlands, where this study was conducted, $33 \%$ of first-year university students do not continue to the second year of the programme they initially started (Inspectie van het Onderwijs 2016). A smooth transition from secondary school to university increases the chances of student success, in terms of achievement and persistence (Lowe and Cook 2003; Rienties et al. 2012). Therefore, it is important for university educators to understand how to improve this transition for students. An effective measure of how well a student has transitioned to university is the level of academic adjustment to this new environment. In this study, we draw on traditional theories of student success [e.g. Tinto (1993) and Astin (1999)] and earlier research on academic adjustment (Baker and Siryk 1989) and conceptualise academic adjustment as the ability to have successful interactions with the new academic environment and to cope with its academic demands. In other words, it revolves around the fit between the student and the university environment (Ramsay et al. 2007). To make the concept of academic adjustment more explicit, we follow Baker and Siryk's (1984) categorisation of four aspects of academic adjustment, which are motivation to learn and having clear academic goals, applying oneself to academic work, exerting effort to meet academic demands and being satisfied with the academic environment. Previous research consistently showed that academic adjustment influences academic achievement (Bailey and Phillips 2016; Rienties et al. 2012).

This study has two goals. First, we aim to determine which motivational and behavioural variables measured in the first year of university affect students' academic adjustment and success, i.e. grade point average (GPA), number of attained study credits [European Credit Transfer and Accumulation System (ECTS)] and intention to persist after 3 months of study. An important question here is which variables influence student success, either directly or indirectly through adjustment. Second, we investigate the magnitude of the influence of academic adjustment on the three outcome variables. Most research only uses one outcome measure, even though the specific outcome measure chosen may affect the results. Robbins et al. (2004) showed, for example, that the impact of predictive factors differs for achievement and persistence. Moreover, these outcome measures in themselves differ. A student's GPA reflects how well a student performs, whereas the number of credits merely shows whether a student is passing courses. Persistence is yet another distinct measure of success, in that students with a high GPA and many credits may drop out, whereas students with low GPAs or few credits may choose to persist. The differences in measures of success makes it important to include all of them and investigate whether academic adjustment affects them differently.

The motivational and behavioural input variables on which we focus appear in prior literature as important correlates of student success and academic adjustment in university and will be discussed below. 


\section{Theoretical framework}

\section{Academic adjustment influencing student success}

Research on student success in higher education has a rich history. The traditional theories of Tinto (1993) and Astin (1999) focus on the interaction between the student and the institution, where Tinto's theory of student attrition includes academic, social and institutional integration and goal commitment and Astin's student development theory revolves around student involvement, which he defines as the energy that a student devotes to the academic experience (Astin 1999). The common ground lies therein that a student enters higher education with certain personal characteristics, e.g. personality, motivation, study skills, which change and may even be challenged in interaction with the new educational environment. Successful interaction with this new environment, such as having positive interactions with lecturers and fellow students and being able to handle the increased complexity and quantity of the learning content, then determines whether or not a student is satisfied with the first-year experience and whether he or she obtains good grades, passes his or her courses and persists to the second year (Astin 1999; Pascarella and Terenzini 2005; Sevinç and Gizir 2014). Successful interaction between a first-year student and the academic characteristics and demands of the university environment can be summarised by the construct of academic adjustment. Prior literature consistently showed the pivotal role of academic adjustment in predicting achievement (Aspelmeier et al. 2012; Rienties et al. 2012; Wintre et al. 2011) and persistence (Kennedy et al. 2000; Kuh et al. 2006) in higher education. Some studies even reported that the effects of background variables on achievement were indirect, with adjustment as a mediator (Kamphorst et al. 2012; Petersen et al. 2009). Moreover, academic adjustment explained variance in achievement beyond secondary school GPA (McKenzie and Schweitzer 2001). Lowe and Cook (2003) found that 20 to $30 \%$ of university students experienced considerable difficulty adjusting to higher education, leading a significant number to drop out or underperform. These factors make academic adjustment an important concept when investigating student success.

\section{Correlates of student success and academic adjustment}

Because of the aforementioned importance of academic adjustment as a correlate of first-year success, it is useful to know which variables influence adjustment. Robbins et al. (2004) emphasised the importance of combining motivational factors and study skills when explaining academic achievement, and Kennedy et al. (2000) warned against using too narrow a range of variables. We followed this line of thought to explain adjustment and included different motivational and behavioural factors in our model to obtain a more integrative view of adjustment and achievement.

\section{Motivational correlates of success and adjustment}

Intrinsic motivation Meta-analyses on academic achievement showed a consistent relationship between motivation and achievement (Richardson et al. 2012; Robbins et al. 2004). Other studies investigated the link between motivational factors and adjustment. For example, Lynch (2006) and Petersen et al. (2009) reported a positive link between intrinsic motivation and adjustment. Baker and Siryk (1984) showed that achievement motivation was correlated with 
academic adjustment. Moreover, Baker (2004) showed that lack of motivation is related to poorer adjustment to university. Following these findings and the expectation that students who are intrinsically motivated to study a certain topic will find it easier to adjust to an educational environment where they get the opportunity to study this topic, we expected intrinsic motivation to have a direct and an indirect effect on achievement through adjustment.

Academic self-efficacy According to Robbins et al.'s (2004) meta-analysis, academic selfefficacy is the strongest non-cognitive correlate of GPA. Self-efficacy is a person's perception of the ability to perform adequately in a given situation (Bandura 1997). Academic selfefficacy in the university context thus refers to a student's confidence that he or she can perform adequately in the university environment. Besides being an important correlate of achievement, academic self-efficacy relates to effort and perseverance in learning, self-regulation, less stress in demanding situations and better adjustment to new learning situations (Chemers et al. 2001). McKenzie and Schweitzer (2001) found that the prediction of GPA improved by $12 \%$ when academic integration and self-efficacy were added to a model with university entry score as a predictor. De Clercq et al. (2013), who used an inclusive approach that took into account several predictors, also reported that self-efficacy was one of the most powerful predictors of GPA at the end of the first year in university. When investigating persistence as an outcome measure, Kennedy et al. (2000) found no differences in self-efficacy between students who continued their studies after 1 year and those who did not. Still, there is some evidence that self-efficacy could affect persistence, because Willcoxson et al. (2011) found that the opposite of academic self-efficacy, lack of academic confidence, caused students to give up their studies. Examining the relationship between academic self-efficacy and adjustment, several studies showed that self-efficacy, or the comparable concept of academic self-confidence, positively affected adjustment (Chemers et al. 2001; Martin et al. 1999). This finding can be explained by Bandura's (1997) self-efficacy theory, which states that people high in efficacy show more persistence in the face of challenges. The transition from secondary education to university is such a challenge. Moreover, Aspelmeier et al. (2012), who found that self-esteem and internal locus of control had a positive effect on first-year students' academic adjustment, suggested that academic self-efficacy is an important factor to consider in future research on adjustment. We thus hypothesised that academic self-efficacy influences achievement both directly and via adjustment.

Degree programme satisfaction Although models explaining university success included degree programme satisfaction less often than motivation and self-efficacy, it may be crucial for predicting persistence (Suhre et al. 2007; Yorke and Longden 2007), especially in the Netherlands and many other European countries such as Germany and Belgium, where students entering university immediately start in a specific major. Not being satisfied with the programme is one of the most important determinants of dropping out (De Buck 2009; Wartenbergh and Van den Broek 2008). Moreover, satisfaction relates to achievement; Suhre et al. (2007) showed that students who were more satisfied obtained more credits. We know of no research that investigates the relationship between degree programme satisfaction and academic adjustment, but we expect that students who are satisfied can better cope with academic demands. In the first few weeks of the programme, where students immediately start with several courses specific to the degree programme they chose, students already get a good view of what the programme entails and they can judge the extent to which the programme meets their expectations and the extent to which they are satisfied with the programme. 
Adjustment to the whole first-year experience, which includes among other things adjusting to a new way of learning, to more independency, and to a faster learning pace, however, is a process that takes longer. The rationale here is that when students are satisfied with the programme they chose, the process of adjusting academically may be easier. On the contrary, students who are having doubts regarding whether this specific degree programme matches their interests may be preoccupied with the dilemma of whether or not to proceed with this programme, which may also have a negative effect on their process of adjusting to university. Their doubts about the programme may even transfer into doubts about belonging in university altogether. Thus, we expected degree programme satisfaction to be related to academic adjustment, achievement and persistence.

\section{Behavioural correlate of success and adjustment}

Self-regulated study behaviour Motivation is an important but insufficient condition to perform well in university. As Robbins et al. (2004) concluded, it is important to include study skills, along with psychosocial variables, in models predicting achievement. Selfregulation is a specifically important skill in the university environment, where students must regulate their own study behaviour. Moreover, students who live independently may have many personal and social demands that compete with academic demands. At this point, behaviour regulation becomes crucial. According to Pintrich (2004), behaviour regulation is part of self-regulation, referring to individual attempts to control one's own behaviour. Important behaviour regulation activities in the academic environmentor self-regulated study behaviour - are effort regulation, time management and environment management. Effort regulation refers to the ability to control the allocation and intensity of effort, with the goal of doing well in a course; time management involves activities such as making schedules for studying and allocating time for different activities; and environment management pertains to finding the optimal physical conditions for a learning environment, such as avoiding distractors (e.g. social media [Jacobsen and Forste 2011]) or people (Pintrich 2004). Effort, time and environment regulation are among the study skills often connected to achievement (Burlison et al. 2009; Lynch 2006). A meta-analysis of the Motivated Strategies for Learning Questionnaire (MSLQ) even showed that of all learning strategies included in the MSLQ, effort regulation and time and study environment management had the highest observed validities for predicting GPA (Credé and Phillips 2011). In addition, Wintre et al. (2011) reported that first-year students who maintained their secondary school GPA in the first year of higher education had better time management skills than those whose GPA would drop and Hurtado et al. (2007) found that students' time management skills was a significant predictor of academic adjustment. In contrast with university lecturers' expectations, first-year students often do not possess the self-regulatory skills that the university environment demands, because they are accustomed to the structured and supervised situation in secondary education (Cook and Leckey 1999). This lack of regulatory skill could cause adjustment problems in university; Abott-Chapman et al. (1992) showed that students with insufficient study skills were at risk of academic adjustment problems. We therefore expected self-regulated study behaviour to influence adjustment and achievement. 


\section{Previous achievement as a predictor of success and adjustment}

Much research indicated that past achievement is a predictor of university achievement (Bowles et al. 2014; McKenzie and Schweitzer 2001; Richardson et al. 2012; Robbins et al. 2004; Suhre et al. 2007). However, it is equivocal whether past achievement (i.e. secondary school GPA) also influences academic adjustment at university. It seems reasonable to expect that students with higher scores in secondary education will be better equipped to cope with academic demands and thus adjust to university more easily (Baker and Siryk 1989; Kaczmarek et al. 1990). However, Wouters et al. (2011) found no relationship between achievement in secondary education and academic adjustment in higher education, so we questioned whether to expect a pathway from secondary school GPA to adjustment in university.

\section{The conceptual model}

Figure 1 presents a schematic representation of the conceptual model of motivational and behavioural factors influencing academic adjustment and the three measures of student success. We expected intrinsic motivation, academic self-efficacy, self-regulated study behaviour and satisfaction with degree programme choice to relate to academic adjustment, as well as to the measures of student success, GPA, credits and intention to persist.

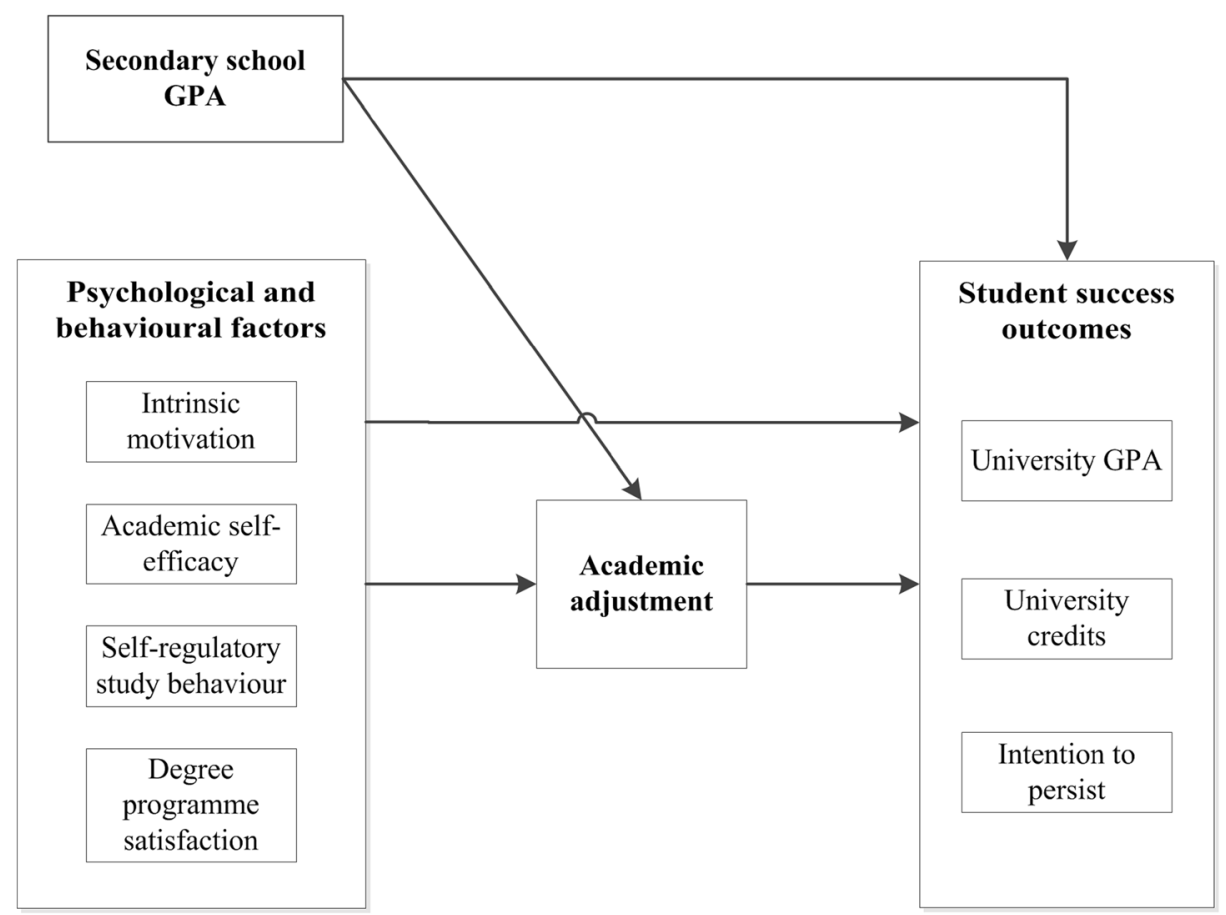

Fig. 1 Conceptual model of motivational and behavioural factors impacting academic adjustment and student success outcomes 


\section{Educational context}

There are two characteristics of the Dutch secondary and higher education system that are relevant in this study. First, in the Netherlands, as in many other European countries, the secondary school system is differentiated: from grade 7 onwards, students attend a level of secondary education that matches their capabilities. Pre-university education is the highest of the three existing levels and graduating from pre-university grants access to a degree programme at a research university. For some programmes, additional requirements are at play, such as specific subject uptake in pre-university education, but in general, the application process is not as intense as in for example the USA. Second, also quite common in Europe, students entering university choose the degree programme they major in before they start.

\section{Method}

\section{Sample}

The total sample was a convenience sample that consisted of 243 first-year university students from different research-intensive universities in the Netherlands, who completed the questionnaire approximately 3 months after the start of their programme. Many different degree programmes were represented in the sample, but a large majority of the students were pursuing a social sciences degree (77\%), e.g. Spatial Sciences, Sociology and Law, and a smaller number of students were in the humanities $(4 \%)$ and natural sciences (19\%). Women were overrepresented in this study $(60 \%$, as opposed to $53 \%$ in the population of first-year university students in the Netherlands; Sociaal en Cultureel Planbureau [SCP] 2014). Most students started university after graduating from preuniversity education (82\%); 14\% came from higher vocational education, and the other $4 \%$ had switched from another programme at university. Students' average age was 19.13 years (SD 1.57), ranging from 17 to 28 years, hence the sample can be seen as a sample of traditional students. This makes the sample representative, as in the Netherlands $80 \%$ of all pre-university students directly continue to university education (Centraal Bureau voor de Statistiek [CBS] 2016). Furthermore, 24\% of students can be classified as first-generation university students, students of whom neither of their parents had attended higher education. Among all first-year university students in the Netherlands, the percentage of first-generation students is 33\% (Van den Broek et al. 2014).

\section{Measures}

\section{Student success outcomes}

GPA Students indicated the average grade they obtained for the courses they had taken in the first quarter of the study year. In the Dutch education system, grades range from 1 to 10 , and a 5.5 or higher is required to pass. The students' grades in this sample ranged from 4 to 9 , with an average grade of $6.90(\mathrm{SD}=0.98)$.

Credits In addition to their GPA, students reported the number of credits they had obtained in the first quarter of the year. 
Intention to persist We measured students' intention to persist with one question: 'Do you intend to finish this degree programme (i.e. the 3-year university bachelor's program)?'

\section{Academic adjustment}

We measured students' academic adjustment with the academic adjustment subscale of the Student Adaptation to College Questionnaire (SACQ) by Baker and Siryk (1984). This subscale consists of 24 questions that involve coping with the academic demands of the university experience. In line with Baker and Siryk's internal consistency measures for the scale, which range from $\alpha=.82$ to .87 , and with more recent studies who used the academic adjustment subscale of the SACQ [e.g. Jones et al. (2015) and RodríguezGonzález et al. (2012)], the alpha of this scale in our study was good: .85.

\section{Motivational factors}

Intrinsic motivation We used a measure of intrinsic motivation specifically focused on the university environment, i.e. a desire to gain academic knowledge in one's field of interest and to conduct research because one finds it inherently interesting or enjoyable (based on Ryan and Deci 2000). The 13 items were based on the Scientific Attitude Inventory II (SAI II; Moore and Foy 1997).

Academic self-efficacy To measure academic self-efficacy for the university environment, we used 16 of the 33 items of the College Academic Self-Efficacy Scale (CASES; Owen and Froman 1988). Previous research has shown that these items were sufficient to obtain a reliable measure of academic self-efficacy (Van Rooij et al. 2017). The 16 items were typical behaviours that students need to demonstrate at university, such as being able to understand difficult passages in textbooks and attending class consistently even in a dull course.

Degree programme satisfaction We measured the extent to which the university students were satisfied with the degree programme they had chosen by averaging the score on two items: 'I am satisfied with the programme I chose' and 'Looking back, I wish I had chosen a different degree programme' (reverse coded).

\section{Behavioural factor: self-regulated study behaviour}

The self-regulated study behaviour scale consisted of the effort regulation and the time and study environment management subscales of Part B of the Motivated Strategies for Learning Questionnaire (MSLQ) (Pintrich et al. 1993). The effort regulation scale had four items, and the time and study environment management subscale consisted of eight items. Credé and Phillips's (2011) meta-analyses of the MSLQ showed that the scales of time and study environment management and effort regulation were so strongly correlated that they may assess the same construct. Correspondingly, the internal consistency of the complete selfregulated study behaviour scale was good $(\alpha=.87)$. Table 1 summarises measurement characteristics. 
Table 1 Measurement characteristics of the motivational and behavioural factors

\begin{tabular}{|c|c|c|c|c|}
\hline Factor & Sample items & $\begin{array}{l}\text { Number } \\
\text { of items }\end{array}$ & $\begin{array}{l}\text { Scale } \\
\text { range }\end{array}$ & $\begin{array}{l}\text { Cronbach's } \\
\text { alpha }\end{array}$ \\
\hline $\begin{array}{l}\text { Academic } \\
\text { adjustment }\end{array}$ & $\begin{array}{l}\text { I keep up-to-date with academic work. } \\
\text { I find academic work difficult. (reverse coded) }\end{array}$ & 24 & $1-5$ & .85 \\
\hline $\begin{array}{l}\text { Intrinsic } \\
\text { motivation }\end{array}$ & $\begin{array}{l}\text { I like to gain more academic knowledge in the field of my } \\
\text { interest. } \\
\text { Looking for new research-based knowledge is boring. } \\
\text { (reverse coded) }\end{array}$ & 13 & $1-5$ & .88 \\
\hline $\begin{array}{l}\text { Academic } \\
\text { self-efficacy }\end{array}$ & $\begin{array}{l}\text { (How confident are you that you can perform this task } \\
\text { well?) Understanding difficult passages in textbooks. } \\
\text { Taking well-organised notes during a lecture. }\end{array}$ & 16 & $1-5$ & .74 \\
\hline $\begin{array}{l}\text { Degree } \\
\text { programme } \\
\text { satisfaction }\end{array}$ & $\begin{array}{l}\text { I am satisfied with the programme I chose. } \\
\text { Looking back, I wish I had chosen a different degree } \\
\text { programme. (reverse coded) }\end{array}$ & 2 & $1-5$ & .80 \\
\hline $\begin{array}{l}\text { Self-regulated } \\
\text { study } \\
\text { behaviour }\end{array}$ & $\begin{array}{l}\text { I find it hard to stick to a study schedule. (reverse coded) } \\
\text { I usually study in a place where I can concentrate on my } \\
\text { course work. }\end{array}$ & 12 & $1-7$ & .87 \\
\hline
\end{tabular}

\section{Previous achievement}

We determined academic achievement in secondary school with an item that asked for average secondary school diploma grade. Scores ranged from 6 (satisfactory) to 9 (very good), with an average grade of $7.07(\mathrm{SD}=.72)$.

\section{Procedure}

The Ethics Committee of the university had given approval of the study. All participants received an e-mail invitation to participate in the study. Seventy-one percent of participants received this e-mail, composed by the researchers, via a coordinator of their programme who was interested in having the first-year students of his or her programme participate in the study and the other $29 \%$ received the invitation directly from the researchers. This latter group participated in a previous study a year earlier, when they were still in secondary school, and had given consent to be contacted again for a follow-up study. The e-mail invitation explained the research purpose and asked the student to complete an online questionnaire; participation was voluntary. Incentives were allotted among participants who had completed the questionnaire. The response rate was $52 \%$.

\section{Analyses}

Due to 11 students having missing values on multiple variables, we based our structural equation model tests on 232 first-year university students. We used Mplus, Version 7, to perform the analyses. First, we inspected the descriptive statistics and correlational matrix to conclude whether certain variables were significantly and substantially related to each other. Second, using these results, we decided which variables to include in the first model, based on the conceptual model with both direct and indirect links from the motivational and behavioural factors to the student success outcomes. Third, we tested this first model and evaluated its goodness of fit based on agreed-upon criteria (e.g. Kline 2005). Fourth, if the model fit was 
insufficient, we adapted the model, according to the reported modification indices and theoretical considerations, after which we tested the new model.

\section{Results}

\section{Descriptive results}

Table 2 presents the descriptive statistics of all factors used in the model. The mean scores on all factors, as well as on secondary school and university GPA, were relatively high and the variances, especially those of academic adjustment and academic self-efficacy, were quite low. There were no significant differences in factor and outcome means between first-generation students and continuing generation students. We also did not find any significant differences between students who came from pre-university, from higher vocational education and from another university degree programme.

Table 3 shows the correlations between all factors used in the model. The motivational and behavioural variables had higher correlations with academic adjustment than with the three measures of student success, with the exception of degree programme satisfaction, which correlated equally strongly with intention to persist and academic adjustment.

\section{Path analysis}

As can be deduced from Fig. 1, our conceptual model consisted of many links, between each of the motivational and behavioural variables and academic adjustment and each of the student success outcomes. However, because correlations lower than .25 would likely have resulted in insignificant links in the model, we excluded the hypothesised pathways between intrinsic motivation and GPA, ECT and intention to persist, and those between academic self-efficacy and ECT and intention to persist. We then tested this model in Mplus. Goodness-of-fit statistics showed that this model had good fit $\left(X^{2}(11)=14.91, p=.07, X^{2} / \mathrm{df}=1.36\right.$, RMSEA $=.04$ [confidence interval $=.00-.08], \mathrm{CFI}=.99, \mathrm{TLI}=.98, \mathrm{SRMR}=.06)$. However, many of the pathways were insignificant: secondary school GPA and academic self-efficacy were not

Table 2 Descriptive statistics

\begin{tabular}{lccc}
\hline Variable & M & SD & Min-Max \\
\hline Secondary school GPA & 7.07 & .72 & $6-9$ \\
University GPA $^{\text {University credits }}{ }^{\mathrm{a}}$ & 6.90 & .98 & $4-9$ \\
Intention to persist $^{\mathrm{b}}$ & 4.42 & 1.10 & $1-5$ \\
Academic adjustment $^{\text {Intrinsic motivation }}$ & 4.66 & .69 & $1-5$ \\
Academic self-efficacy & 3.65 & .45 & $2.27-4.78$ \\
Self-regulated study behaviour & 3.46 & .59 & $1.67-5$ \\
Degree programme satisfaction & 3.64 & .42 & $2.63-4.69$ \\
\hline
\end{tabular}

${ }^{a}$ Because study programmes differ in the possible number of credits a student can attain in the first half of the first semester, credits is an ordinal variable ranging from 1 ('I attained none of the credits that could be attained so far') to 5 ('I attained all of the credits that could be attained so far')

b Students rated their intention to persist on a five-point scale: 1 = 'I will quit this programme', and 5 = 'I am determined to finish this programme' 
Table 3 Correlations between the motivational and behavioural factors and student success outcomes

\begin{tabular}{|c|c|c|c|c|c|c|c|c|}
\hline & 1 & 2 & 3 & 4 & 5 & 6 & 7 & 8 \\
\hline \multicolumn{9}{|l|}{ 1. University GPA } \\
\hline 2. University credits & $.59 * *$ & & & & & & & \\
\hline 3. Intention to persist & $.22 * *$ & $.26^{* *}$ & & & & & & \\
\hline 4. Secondary school GPA & $.48^{* *}$ & $.33 * *$ & .10 & & & & & \\
\hline 5. Academic adjustment & $.44 * *$ & $.47 * *$ & $.35 * *$ & $.27 * *$ & & & & \\
\hline 6. Intrinsic motivation & $.21 * *$ & $.16^{*}$ & $.16^{*}$ & $.21 * *$ & $.28 * *$ & & & \\
\hline 7. Academic self-efficacy & $.34 * *$ & $.20 *$ & .15 & $.22 * *$ & $.55^{* *}$ & $.22 * *$ & & \\
\hline 8. Self-regulated study behaviour & $.44 * *$ & $.36^{* *}$ & .01 & $.37 * *$ & $.71 * *$ & .10 & $.57 * *$ & \\
\hline 9. Degree programme satisfaction & $.27 * *$ & $.27 * *$ & $.60 * *$ & .11 & $.60 * *$ & $.17 *$ & $.23 * *$ & $.24 *$ \\
\hline
\end{tabular}

$* p<.05 ; * * p<.01$

significantly related to academic adjustment; self-regulated study behaviour and satisfaction with the choice of degree programme were not significantly related to GPA; secondary school GPA, self-regulated study behaviour and satisfaction with the programme were not significantly related to credits; and academic adjustment was not significantly related to intention to persist.

These results implied that many links from the motivational and behavioural variables affected university success outcomes not directly but through adjustment. Therefore, we tested a second model in which we removed all insignificant pathways from the first model. We present this model in Fig. 2. This model achieved good fit: $X^{2}(19)=20.55, p=.36, X^{2}$ / $\mathrm{df}=1.08, \mathrm{RMSEA}=.02[\mathrm{CI}=.00-.06], \mathrm{CFI}=.99, \mathrm{TLI}=.99, \mathrm{SRMR}=.06$. All hypothesised links were significant, except the link from academic self-efficacy to university GPA $(\beta=.13$ $(\mathrm{SE}=.06), p=.06)$. Moreover, university GPA and intention to persist were not significantly related to each other $(\beta=.12(\mathrm{SE}=.07), p=.12)$ and neither were self-regulated study behaviour and intrinsic motivation $(\beta=.14(\mathrm{SE}=.08), p=.10)$. The model showed that the motivational and behavioural variables affected two university success outcomes, GPA and credits, through academic adjustment. Self-regulated study behaviour $(\beta=.61)$, intrinsic motivation $(\beta=.14)$ and satisfaction with the choice of degree programme $(\beta=.36)$ had impacts on academic adjustment. Academic self-efficacy was not significantly related to university GPA, but did correlate highly with self-regulated study behaviour ( $\beta=.63$ ), thereby indirectly influencing adjustment and subsequent achievement. In total, $72 \%$ of the variance in academic adjustment was explained by the aforementioned variables. Academic adjustment influenced both GPA $(\beta=.38)$ and the number of attained credits $(\beta=.50)$ in university. Secondary school GPA only had impact on university GPA $(\beta=.28)$. Respectively, 29 and $25 \%$ of the variance in GPA and credits were explained. The intention to persist was largely influenced by students' satisfaction with the degree programme they had chosen $(\beta=.60)$.

\section{Discussion}

\section{Conclusions and discussion of the main findings}

We investigated which motivational and behavioural variables measured in the beginning of the first year of university affected students' academic adjustment and success (GPA, credits and intention to persist) and the influence of academic adjustment in predicting these three 


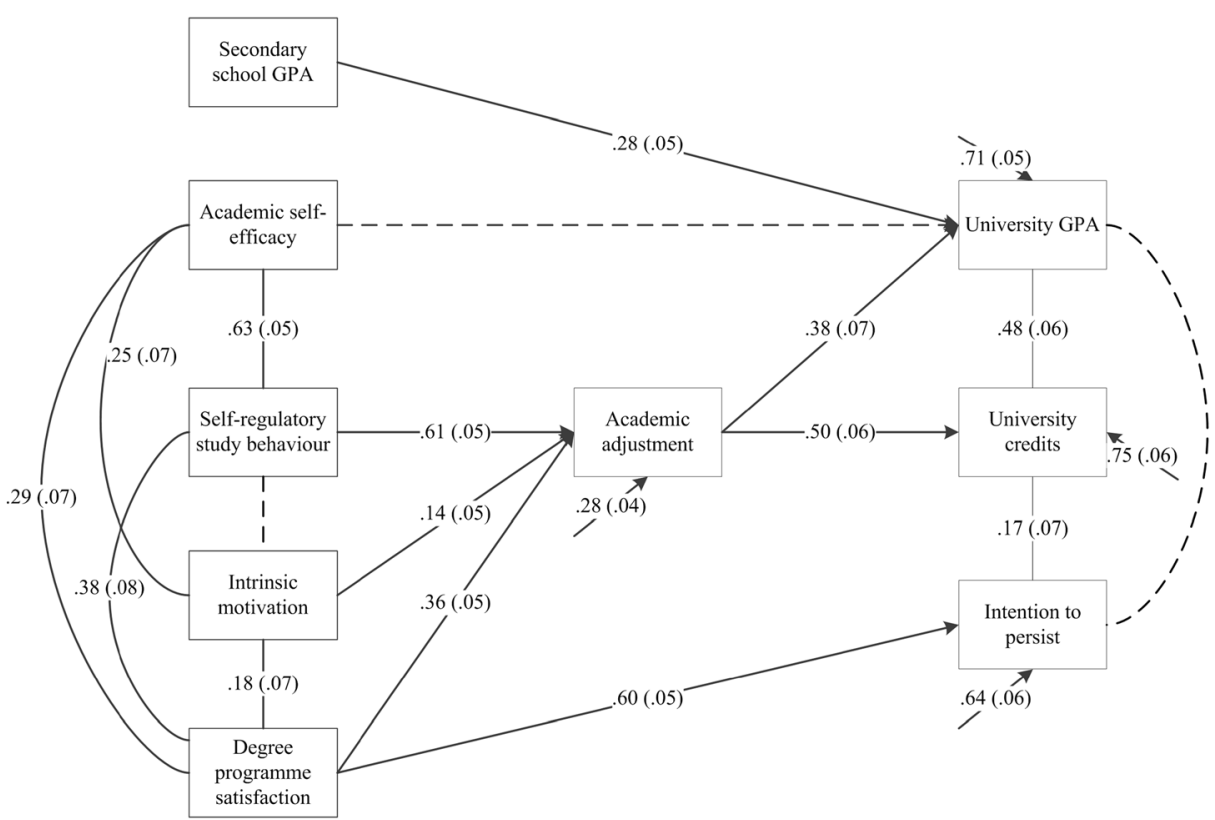

Fig. 2 Fitted model of motivational and behavioural factors impacting academic adjustment and student success outcomes. Note: dotted lines represent insignificant pathways

outcomes. Students who were more intrinsically motivated to gain academic knowledge and to do research, who could effectively regulate their study behaviour and who were more satisfied with their chosen degree programme had better academic adjustment (i.e. had more successful interactions with the academic experience and were better able to cope with the academic demands of the university environment). Furthermore, students with better academic adjustment and who had a higher GPA in secondary education had a higher university GPA. In addition, better academic adjustment led to more credits in the first half of the first semester of university. However, whether these students actually intended to persist was a different question: it depended less on the level of academic adjustment and secondary school GPA than on their satisfaction with their chosen degree programme. Our results thus confirmed the importance of academic adjustment as a measure of how successfully the student transitioned from secondary school to higher education in predicting study results in the first year of university. In addition, academic adjustment was substantially more important in predicting the number of attained credits and university GPA than secondary school GPA. Thus, it is again confirmed that first-year students' experiences, more specifically how they interact with the learning environment, have more impact on their success than their previous results (Kuh et al. 2006). Motivational and behavioural factors did not influence GPA and credits directly but only through academic adjustment. Thus, effectively regulating study behaviour (e.g. maintaining study schedules, turning off social media when studying), being intrinsically motivated to gain academic knowledge and being satisfied with chosen degree programme did not necessarily mean students would achieve high grades and obtain all credits. It did, however, increase their chances of being well-adjusted (i.e. able to cope with the academic demands of the new learning environment). Subsequently, this academic adjustment led to a better GPA 
and more credits. Studies that tested the effects of these motivational and behavioural factors as having only direct effects on achievement may underemphasise the pivotal role of adjustment.

Another important finding was that self-regulated study behaviour exerted the largest influence on academic adjustment of all measured variables. This means that in order to experience a smooth transition, it is very important that students are capable of regulating their study behaviour and less important that they are intrinsically motivated and satisfied with the degree programme. The high degree of self-regulation that university demands is one of the largest differences with secondary school; therefore, students who are good self-regulators will adjust more easily. Another possible explanation is that behavioural factors are more important in explaining adjustment than motivational ones. In this regard, Astin's claim about student involvement can be applied to academic adjustment as well: "It is not so much what the individual thinks or feels, but what the individual does, how he or she behaves" (Astin 1999, p. 519). Furthermore, the differences in magnitude of influence on adjustment could be attributable to smaller differences between students in intrinsic motivation than in selfregulated study behaviour.

A surprising result was that academic self-efficacy, widely accepted as a very important correlate of student success (e.g. Robbins et al. 2004), did not affect any of the student success outcomes of our study, nor did it affect academic adjustment. Its only role in the model was as an important correlate of self-regulated study behaviour, consistent with previous research indicating high correlations between self-regulation and self-efficacy (Bouffard-Bouchard et al. 1991; Fenollar et al. 2007). Again, a possible explanation is that behavioural factors are more important in influencing adjustment than motivational factors such as self-efficacy and that the differences between students in self-efficacy were rather small. Two other explanations are provided by De Clercq et al. (2017), who found a relationship between self-efficacy and achievement that was less strong than expected in their person-centred study on first-year achievement. As they explained, global self-efficacy, such as the general measure of academic self-efficacy that we used in this study, is not as good a predictor as domainspecific self-efficacy, e.g. self-efficacy in a specific subject or a specific skill, and self-efficacy beliefs are not good predictors of achievement in new learning contexts, such as the first year at university (De Clercq et al. 2017). However, we did find that students who were more confident in their academic skills tended to regulate their effort and manage their study time and environment more effectively than students lower in self-efficacy. Because self-regulated study behaviour is very important in university - where instructors provide little control or structure and more autonomy and responsibility is demanded of students (Pintrich 2004) self-efficacy is still an important factor in the transition from secondary to university education due to its influence on behaviour regulation.

Contrary to our expectation, only one variable influenced students' intention to persist, namely, the level of satisfaction with their chosen degree programme. Although this satisfaction also influenced academic adjustment, academic adjustment did not have any influence on intention to persist. Thus, whether a student planned to continue his or her studies after the first year was not related to how well the student could cope with the demands of the academic environment in general, but rather how well he or she fitted within the specific study programme. The outcome variable, intention to persist, thus measured a different entity than the outcome variables GPA and credits, which did not directly relate to a specific degree programme. If we had measured intention to persist as a students' intention to stay in university altogether or drop out completely, academic adjustment may have played a role. 


\section{Implications}

The results indicated the crucial role of academic adjustment in predicting achievement in university. Self-regulated study behaviour, satisfaction with degree programme choice and, to a lesser extent, intrinsic motivation influenced students' academic adjustment. All these factors can be influenced, both before and after the transition. For example, secondary education could emphasise the development of self-regulated study behaviour. Jansen and Suhre (2010) showed that study skills preparation in secondary school, regarding time management and learning skills, positively influenced university students' study behaviour. We also found a connection between academic self-efficacy and selfregulated study behaviour (e.g. Bouffard-Bouchard et al. 1991). Schunk and Ermter (2000) stated that when either of these aspects is low or lacking, the other aspect cannot fully develop, because they influence each other reciprocally. Therefore, they recommended addressing self-efficacy and selfregulatory competence together: interventions that teach self-regulation skills should contain components that increase students' confidence in their academic skills (Schunk and Ermter 2000).

University staff should temper their expectations of first-year students' self-regulation skills. Previous studies showed that many first-year lecturers believe students already possess these skills (Cook and Leckey 1999), and therefore, they do not emphasise (further) development of these skills, even though they are crucial to student success. Paying attention to study skill development, however, may produce positive effects. Interventions focused on the development of academic skills led to gains in academic achievement (Evans and Burck 1992). Promoting good study behaviour alone may not be sufficient, in that intrinsic motivation also influenced adjustment. Moreover, many researchers emphasised the importance of combining study skills factors and motivational factors to boost students' achievement (Eccles and Wigfield 2002; Pintrich et al. 1993; Robbins et al. 2004). Of Zepke and Leach's (2010) ten proposed actions to enhance higher education students' engagement, the first two focus on increasing motivation: enhancing students' self-belief and enabling students to work autonomously, enjoy learning relationships with others and feel they are able to reach their own goals. These actions could be a meaningful starting point to increase motivation.

Whereas self-regulation skills and motivation can be positively influenced when the student already is in university, this is to a lesser extent the case with students' satisfaction with their chosen programme. There is not much that can be done when the student has simply chosen a programme that is not what he or she expected it to be and thus does not match his or her abilities, interests and values. Switching programmes then is a good solution. Because of this large influence we found of satisfaction with the programme on persistence [which is in line with a study by Jansen and Suhre (2010)], it is worthwhile to help prospective students make a good programme choice. Both secondary schools and universities play important roles in this regard. Secondary schools could provide students with the opportunity to get to know the programmes in which they are interested - for example, by having them write a comparative essay of three study programmes, which would encourage them to go in depth to investigate the study programmes and the extent to which they fit the students' individual strengths, interests, values and learner characteristics. Universities could provide information for prospective students in such a way that their expectations of a programme will be realistic. Information should be transparent about crucial characteristics of the study, such as the curriculum, the degree of difficulty, the level of guidance and availability of staff, the available facilities of the university and so on. Last, since both universities and secondary schools are important parties in the transition, it would be beneficial if they would communicate and collaborate more. 


\section{Limitations and directions for future research}

A first limitation of the current study was that we only accounted for academic adjustment, not for other types of adjustment. Although it is the most consistent correlate of achievement compared with other types (Rienties et al. 2012), measuring social, personal-emotional and institutional adjustment in addition could be valuable. Second, there were some limitations regarding the sample: it was a convenience sample that consisted of students from several universities and degree programmes without taking these differences into account. Although interesting for future research, investigating differences between fields or programmes was not the intention of this study and the sample was not sufficiently large to do so. Looking at the relatively high GPAs, and the relatively small variance of measures as self-efficacy and academic adjustment that we found, it seems likely that the sample was biased towards the better performing students. We know from research on response bias that it is a familiar problem that higher-achieving students are more inclined to complete surveys than their lower-achieving peers (Sax et al. 2003). Therefore, it is important to validate these results with a larger and more diverse sample. In this regard, especially the absence of a link between self-efficacy and academic adjustment would be worthwhile to re-investigate. If the variance between both factors would be increased the model may behave differently. Third, we measured all variables at one point in time, which makes it impossible to detect causal relationships and to map processes. Many of the proposed linkages in the conceptual model could arguably be turned around, e.g. academic adjustment could influence self-efficacy. To determine causal relationships, it would be worthwhile to conduct longitudinal research that starts measuring motivational and behavioural variables in secondary school and investigates how they relate to adjustment and student success outcomes later in university. Relatedly, research should investigate whether secondary school teachers are giving adequate attention to preparing students for university. If so, how, and are their practices in line with what students need to be well prepared? In this study, for example, selfregulated study behaviour is very important for first-year university students. Are secondary schools preparing their students to manage their time, environment, and effort efficiently? Moreover, study choice is crucial; students who are dissatisfied with their chosen programme are at a high risk to quit. Researchers could provide a clear image of what teachers and advisors in secondary school currently are doing to help their students make suitable choices and how they could improve those choice processes.

Open Access This article is distributed under the terms of the Creative Commons Attribution 4.0 International License (http://creativecommons.org/licenses/by/4.0/), which permits use, duplication, adaptation, distribution and reproduction in any medium or format, as long as you give appropriate credit to the original author(s) and the source, provide a link to the Creative Commons license, and indicate if changes were made.

\section{References}

Abott-Chapman, J. A., Hughes, P. W., \& Wyld, C. (1992). Monitoring student progress: A framework for improving student performance and reducing attrition in higher education. Hobart: National Clearinghouse for Youth Studies.

Aspelmeier, J. E., Love, M. M., McGill, L. A., Elliott, A. N., \& Pierce, T. W. (2012). Self-esteem, locus of control, college adjustment, and GPA among first- and continuing-generation students: a moderator model of generational status. Research in Higher Education, 53(7), 755-781.

Astin, A. (1999). Student involvement: a developmental theory for higher education. Journal of College Student Development, 40(5), 518-529.

Bailey, T. H., \& Phillips, L. J. (2016). The influence of motivation and adaptation on students' subjective well-being, meaning in life and academic performance. Higher Education Research and Development, 35(2), 201-216. 
Baker, R. W., \& Siryk, B. (1984). Measuring adjustment to college. Journal of Counseling Psychology, 31(2), 179-189.

Baker, R. W., \& Siryk, B. (1989). SACQ: student adaptation to college questionnaire manual. Los Angeles: Western Psychological Services.

Baker, S. R. (2004). Intrinsic, extrinsic, and amotivational orientations: their role in university adjustment, stress, well-being, and subsequent academic performance. Current Psychology, 23(3), 189-202.

Bandura, A. (1997). Self-efficacy: The exercise of control. New York: W. H. Freeman.

Bouffard-Bouchard, T., Parent, S., \& Larivée, S. (1991). Influence of self-efficacy on self-regulation and performance among junior and senior high-school age students. International Journal of Behavioral Development, 14(2), 153-164.

Bowles, A., Fisher, R., McPhail, R., Rosenstreich, D., \& Dobson, A. (2014). Staying the distance: students' perceptions of enables of transition to higher education. Higher Education Research and Development, 33(2), 212-225.

Burlison, J. D., Murphy, C. S., \& Dwyer, W. O. (2009). Evaluation of the motivated strategies for learning questionnaire for predicting academic performance in college students of varying scholastic aptitude. College Student Journal, 43(4), 1313-1323.

CBS (Centraal Bureau voor de Statistiek [Statistics Netherlands]) (2016). Meer vwo'ers direct naar de universiteit [More pre-university students directly to university]. Retrieved from https:/www.cbs.nl/nl-nl/nieuws/2016 /02/meer-vwo-ers-direct-naar-de-universiteit.

Chemers, M. M., Hu, L., \& Garcia, B. F. (2001). Academic self-efficacy and first-year college student performance and adjustment. Journal of Educational Psychology, 93(1), 55-64.

Cook, A., \& Leckey, J. (1999). Do expectations meet reality? A survey of changes in first-year student opinion. Journal of Further and Higher Education, 23(2), 157-171.

Credé, M., \& Phillips, L. A. (2011). A meta-analytic review of the motivated strategies for learning questionnaire. Learning and Individual Differences, 21(4), 337-346.

De Buck, W. (2009). Studiekeuze, informatiegebruik en studie-uitval in het hoger onderwijs [study choice, information use and drop-out in higher education]. Tijdschrift voor Hoger Onderwijs, 27(3), 147-156.

De Clercq, M., Galand, B., Dupont, S., \& Frenay, M. (2013). Achievement among first-year university students: an integrated and contextualized approach. European Journal of Psychology of Education, 28(3), 641-662.

De Clercq, M., Galand, B., \& Frenay, M. (2017). Transition from high school to university: a person-centered approach to academic achievement. European Journal of Psychology of Education, 32, 39-59.

Eccles, J. S., \& Wigfield, A. (2002). Motivational beliefs, values, and goals. Annual Review of Psychology, 53(1), 109-132.

Evans, J. H., \& Burck, H. D. (1992). The effects of career education interventions on academic achievement: a meta-analysis. Journal of Counseling \& Development, 71(1), 63-68.

Fenollar, P., Román, S., \& Cuestas, P. J. (2007). University students' academic performance: an integrative conceptual framework and empirical analysis. British Journal of Educational Psychology, 77(4), 873-891.

Hurtado, S., Han, J. C., Sáenz, V. B., Espinosa, L. L., Cabrera, N. L., \& Cerna, O. S. (2007). Predicting transition and adjustment to college: biomedial and behavioral science aspirants' and minority students' first year of college. Research in Higher Education, 48(7), 841-887.

Inspectie van het Onderwijs [Inspectorate of Education] (2016). De staat van het onderwijs: Onderwijsverslag 2014/2015 [The current state of education. Educational report 2014/2015]. Retrieved from http:/www. onderwijsinspectie.nl/binaries/content/assets/Onderwijsverslagen/2016/de-staat-van-het-onderwijs-20142015.pdf.

Jacobsen, W. C., \& Forste, R. (2011). The wired generation: academic and social outcomes of electronic media use among university students. Cyberpsychology, Behavior and Social Networking, 14(5), 275-280.

Jansen, E. P. W. A., \& Suhre, C. J. M. (2010). The effect of secondary school study skills preparation on first-year university achievement. Educational Studies, 36(5), 569-580.

Jones, H. A., Rabinovitch, A. E., \& Hubbard, R. H. (2015). ADHD symptoms and academic adjustment to college: the role of parenting style. Journal of Attention Disorders, 19(3), 251-259.

Kaczmarek, P. G., Matlock, C. G., \& Franco, J. N. (1990). Assessment of college adjustment in three freshman groups. Psychological Reports, 66(3), 1195-1202.

Kamphorst, J. C., Hofman, W. H. A., Jansen, E. P. W. A., \& Terlouw, C. (2012). Een algemene benadering werkt niet. Disciplinaire verschillen als verklaring van studievoortgang in het hoger onderwijs [A general approach does not work. Disciplinary differences as an explanation of study progress in higher education]. Pedagogische Studiën, 89(1), 20-38.

Kennedy, P. W., Sheckley, B. G., \& Kehrhahn, M. T. (2000). The dynamic nature of student persistence: influence of interactions between student attachment, academic adaptation, and social adaptation. Paper presented at the Annual Meeting of the Association for International Research, Cincinnati, May 21-24.

Kline, R. B. (2005). Principles and practice of structural equation modeling. New York: The Guilford Press. 
Kuh, G. D., Kinzie, J., Buckley, J. A., Bridge, B. K., \& Hayek, J. C. (2006). What matters to student success: a review of the literature. Commissioned report for the National Symposium on postsecondary student success: spearheading a dialog on student success. Washington, DC: National Postsecondary Education Cooperative.

Lowe, H., \& Cook, A. (2003). Mind the gap: are students prepared for higher education? Journal of Further and Higher Education, 27(1), 53-76.

Lynch, D. J. (2006). Motivational factors, learning strategies and resource management as predictors of course grades. College Student Journal, 40(2), 423-428.

Martin, W. E., Swartz-Kulstad, J. L., \& Madson, M. (1999). Psychosocial factors that predict the college adjustment of first-year undergraduate students: implications for college counselors. Journal of College Counseling, 2(2), 121-133.

McKenzie, K., \& Schweitzer, R. (2001). Who succeeds at university? Factors predicting academic performance in first year Australian university students. Higher Education Research and Development, 20(1), 121-133.

Moore, R. W., \& Foy, R. L. H. (1997). The scientific attitude inventory: a revision (SAI II). Journal of Research in Science Teaching, 34(4), 327-336.

Owen, S., \& Froman, R. (1988). Development of an academic self-efficacy scale. Paper presented at the annual meeting of the National Council on Measurement in Education, New Orleans, LA, April 6-8.

Pascarella, E., \& Terenzini, P. T. (2005). How college affects students. A third decade of research. San Francisco: Jossey-Bass.

Petersen, I., Louw, J., \& Dumont, K. (2009). Adjustment to university and academic performance among disadvantaged students in South-Africa. Educational Psychology, 29(1), 99-115.

Pintrich, P. R. (2004). A conceptual framework for assessing motivation and self-regulated learning in college students. Educational Psychology Review, 16(4), 385-407.

Pintrich, P. R., Smith, D. A. R., Garcia, T., \& McKeachie, W. J. (1993). Reliability and predictive validity of the motivated strategies for learning questionnaire (MSLQ). Educational and Psychological Measurement, 53(3), 801-813.

Ramsay, S., Jones, E., \& Barker, M. (2007). Relationship between adjustment and support types: young and mature-aged local and international first year university students. Higher Education, 54(2), 247-265.

Richardson, M., Abraham, C., \& Bond, R. (2012). Psychological correlates of university students' academic performance: a systematic review and meta-analysis. Psychological Bulletin, 138(2), 353-387.

Rienties, B., Beausaert, S., Grohnert, T., Niemantsverdriet, S., \& Kommers, P. (2012). Understanding academic performance of international students: the role of ethnicity, academic and social integration. Higher Education, 63(6), 685-700.

Robbins, S. B., Lauver, K., Le, H., Davis, D., Langley, R., \& Carlstrom, A. (2004). Do psychological and study skills factors predict college outcomes? A meta-analysis. Psychological Bulletin, 130(2), 261-288.

Rodríguez-González, M. S., Tinajero-Vacas, C., Guisande-Couñago, M. A., \& Páramo-Fernández, M. F. (2012). The Student Adaptation to College questionnaire (SACQ) for use with Spanish students. Psychological Reports: Measures \& Statistics, 111(2), 624-640.

Ryan, R. M., \& Deci, E. L. (2000). Intrinsic and extrinsic motivations: classic definitions and new directions. Contemporary Educational Psychology, 25(1), 54-67.

Sax, L. J., Gilmartin, S. K., \& Bryant, A. N. (2003). Assessing response rates and nonresponse bias in web and paper surveys. Research in Higher Education, 44, 409-432.

Schunk, D. H., \& Ertmer, P. A. (2000). Self-regulation and academic learning. Self-efficacy enhancing interventions. In M. Zeidner, P. R. Pintrich, \& M. Boekaerts (Eds.), Handbook of self-regulation (pp. 631-649). Burlington: Academic Press.

SCP (Sociaal Cultureel Planbureau [The Netherlands Institute for Social Research]). (2014). Emancipatiemonitor 2014. Den Haag: Sociaal Cultureel Planbureau.

Sevinç, S., \& Gizir, C. A. (2014). Factors negatively affecting university adjustment from the views of first-year university students: the case of Mersin University. Educational Sciences: Theory \& Practice, 14(4), 13011308.

Suhre, C. J. M., Jansen, E. P. W. A., \& Harskamp, E. G. (2007). Impact of degree program satisfaction on the persistence of college students. Higher Education, 54(2), 207-226.

Tinto, V. (1993). Leaving college: rethinking the causes and cures of student attrition (2nd ed.). Chicago: The University of Chicago Press.

Van den Broek, A., Tholen, R., Wartenbergh, F., Bendig-Jacobs, J., Brink, M., \& Braam, C. (2014). Monitor Beleidsmaatregelen 2014. Studiekeuze, studiegedrag en leengedrag in relatie tot beleidsmaatregelen in het hoger onderwijs [monitor policy measures 2014. Degree programme choice, study behaviour, and student loans related to policy measures in higher education]. Nijmegen: ResearchNed.

Van Rooij, E. C. M., Jansen, E. P. W. A., \& Van de Grift, W. J. C. M. (2017). Secondary school students' engagement profiles and their relationship with academic adjustment and achievement in university. Learning and Individual Differences, 54, 9-19. 
Wartenbergh, F., \& Van den Broek, A. (2008). Studieuitval in het hoger onderwijs: Achtergrond en oorzaken [drop-out in higher education: background and causes]. Nijmegen: ResearchNed.

Willcoxson, L., Cotter, J., \& Joy, S. (2011). Beyond the first-year experience: the impact on attrition of student experiences throughout undergraduate degree studies in six diverse universities. Studies in Higher Education, 36(3), 331-352.

Wintre, M. G., Dilouya, B., Pancer, S. M., Pratt, M. W., Birnie-Lefcovitch, S., Polivy, J., \& Adams, G. (2011). Higher Education, 62(4), 467-481.

Wouters, S., Germeijs, V., Colpin, H., \& Verschueren, K. (2011). Academic self-concept in high school: predictors and effects on adjustment in higher education. Scandinavian Journal of Psychology, 52(6), 586-594.

Yorke, M., \& Longden, B. (2007). The first-year experience in higher education in the UK. Report on phase 1 of a project funded by the Higher Education Academy. Bristol: Higher Education Academy.

Zepke, N., \& Leach, L. (2010). Improving student engagement: ten proposals for action. Active Learning in Higher Education, 11(3), 167-177.

Els C. M. van Rooij (corresponding author). Department of Teacher Education, University of Groningen, Grote Kruisstraat 2/1, 9712 TS Groningen, The Netherlands. Telephone: +31 5036331 99. E-mail address: e.c.m.van.rooij@rug.nl.

Current themes of research

University preparation in secondary education; the transition from secondary education to university; first-year university students' achievement.

\section{Relevant publication}

Van Rooij, E., Jansen, E. \& Van de Grift, W. (2017). Secondary school students' engagement profiles and their relationship with academic adjustment and achievement in university. Learning and Individual Differences, 54, 9-19.

Ellen P. W. A. Jansen. Department of Teacher Education, University of Groningen, Grote Kruisstraat 2/1, 9712 TS Groningen, The Netherlands. Telephone: +31 50363 3644. E-mail address: e.p.w.a.jansen@rug.nl.

Current themes of research

The transition from secondary education to university; assessment and self-selection for teacher education; learning communities in higher education; international students and the international classroom; excellence in higher education.

\section{Relevant publications}

Jansen, E. P. W. A., Andre, S., \& Suhre, C. J. M. (2013). Readiness and expectations questionnaire: a cross-cultural measurement instrument for first-year university students. Educational Assessment Evaluation and Accountability, 25(2), 115-130.

Jansen, E. P. W. A., \& Suhre, C. J. M. (2010). The effect of secondary school study skills preparation on first-year university achievement. Educational Studies, 36(5), 569-580.

Jansen, E. P. W. A., Suhre, C. J. M., \& André, S. (2016). Transition to an international degree programme: Preparedness, first-year experiences and study success of students from different nationalities. In E. Kyndt, V. Donche, K. Trigwell, \& S. Lindblom-Ylänne (Eds.), Higher Education Transitions: Theory and Research (New perspectives on learning and instruction). Routledge.

Jansen, E. P. W. A., \& Van der Meer, J. (2012). Ready for university? A cross national study on students' perceived preparedness for university. Australian Educational Researcher, 39(1), 1-16. 
Wim J. C. M. van de Grift. Department of Teacher Education, University of Groningen, Grote Kruisstraat 2/1, 9712 TS Groningen, The Netherlands. Telephone: +31 503638518 . E-mail address: w.j.c.m.van.de.grift@rug.nl.

Current themes of research

Evidence-based education; teacher development; school didactics.

Relevant publications

Huijgen, T., van de Grift, W., van Boxtel, C., \& Holthuis, P. (2016). Teaching Historical Contextualization: The Construction of a Reliable Observation Instrument. European Journal of Psychology of Education, 1-23.

Maulana, R., Helms-Lorenz, M., \& van de Grift, W. (2016). The role of autonomous motivation for academic engagement of Indonesian secondary school students: A multilevel modelling. In R. B. King, \& A. B. I. Bernardo (Eds.), The psychology of Asian learners: A festschrift in honor of David Watkins (pp. 237-251). Singapore: Springer.

Van de Grift, W., Helms-Lorenz, M., \& Maulana, R. (2014). Teaching skills of student teachers: Calibration of an evaluation instrument and its value in predicting student academic engagement. Studies in Educational Evaluation, 43, 150-159. 